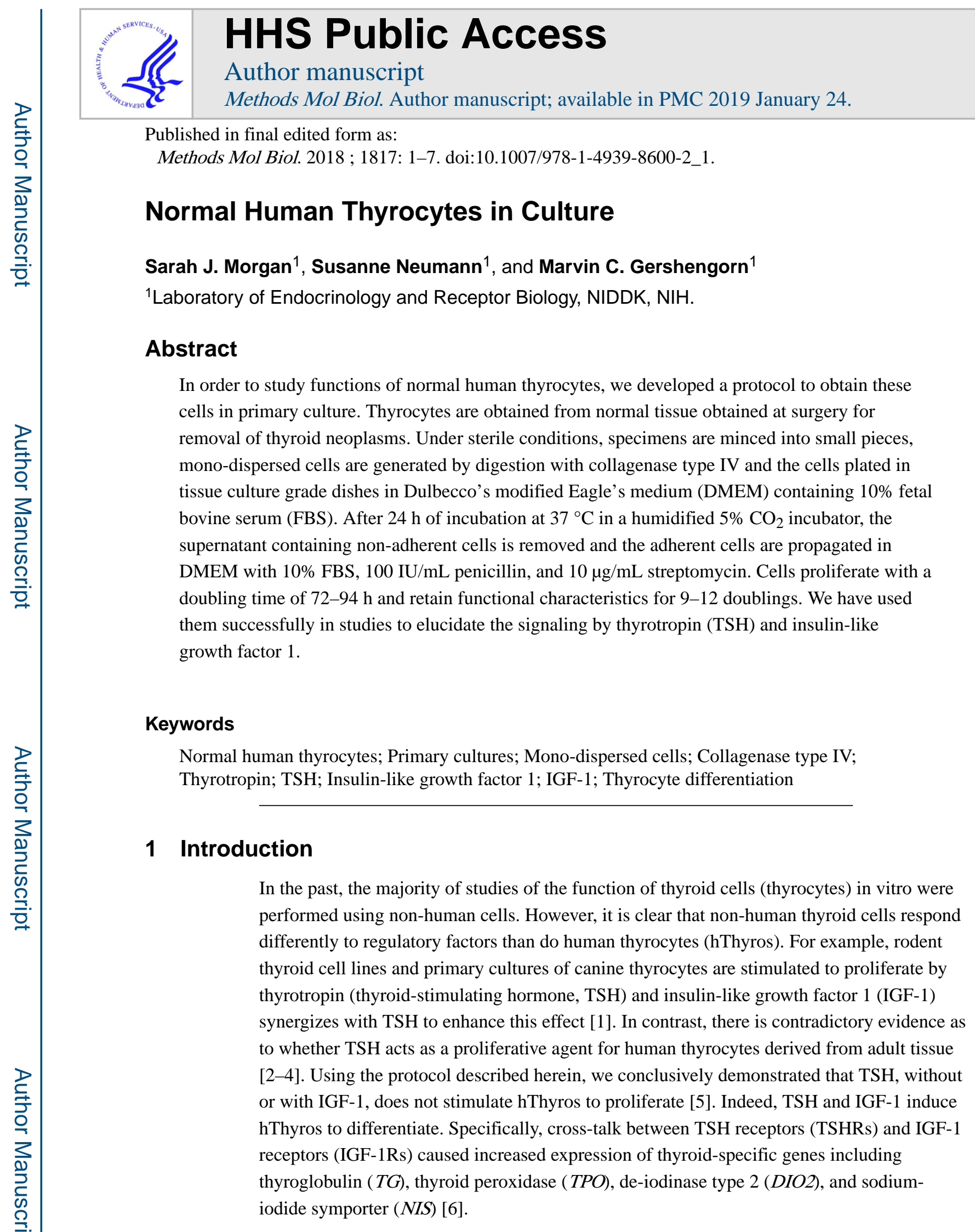

\title{
2 Materials
}

- Hanks' balanced salt solution (HBSS). 
- $\quad$ HBSS containing $3 \mathrm{mg} / \mathrm{mL}$ Collagenase Type IV (sterilize using $0.45 \mu \mathrm{M}$ syringe filter).

- $\quad$ Growth Medium: Dulbecco's Modified Eagle's Medium (DMEM) containing 4.5 $\mathrm{g} / \mathrm{L}$ glucose, L-glutamine, and sodium pyruvate, supplemented with $10 \%$ fetal bovine serum (FBS), $100 \mathrm{U} / \mathrm{mL}$ penicillin, and $10 \mu \mathrm{g} / \mathrm{mL}$ streptomycin.

- NOTE: There is no need to filter media formulations if they are prepared with sterile solutions and under sterile working conditions.

- $\quad$ Arrest/Starvation Medium: DMEM containing $4.5 \mathrm{~g} / \mathrm{L}$ glucose, L-glutamine, and sodium pyruvate, supplemented with $1 \% \mathrm{BSA}$ ( $5 \mathrm{~mL}$ of $10 \%$ prepared solution), $100 \mathrm{U} / \mathrm{mL}$ penicillin, and $10 \mu \mathrm{g} / \mathrm{mL}$ streptomycin.

- $\quad 0.25 \%$ Trypsin/EDTA.

- $\quad$ PBS without calcium and magnesium.

- $\quad$ Freezing Medium: 10\% Dimethyl sulfoxide (DMSO), 90\% FBS.

- $\quad 70 \%$ ethanol, tissue culture plates, sterile pipettes, dissecting forceps and scissors, etc.

\section{Methods}

\subsection{Isolation of Cells from Tissue Samples}

All materials and solutions should be sterile. All manipulation of tissue and cells should be conducted in a cell culture hood (i.e., laminar-flow hood or biosafety cabinet) with use of appropriate personal protective equipment (gloves, lab coat, etc.). Media, trypsin, and other solutions should be warm $\left(37^{\circ} \mathrm{C}\right)$. All tissue manipulations, cell work, and use of media should be done in the cell culture hood using sterile technique. Always check solutions for contamination before using.

Thyroid tissue samples are obtained from patients undergoing partial or total thyroidectomy for thyroid neoplasms. Thus, it is possible to develop normal or diseased (derived from cancer, Graves' disease) thyrocyte cultures as described previously [1, 7]. Patients must provide informed consent on an institutional review board-approved protocol as prescribed by your institution.

Tissue specimens must be maintained in HBSS on ice, and isolation of cells should be initiated as soon as possible and no later than $4 \mathrm{~h}$ following surgery. Mince tissue samples into small pieces with fine surgical forceps and scissors in a $10 \mathrm{~cm}$ dish with a small volume of HBSS. Transfer tissue pieces to a $50 \mathrm{~mL}$ conical tube and wash the plate at least three times with HBSS to collect any additional tissue. Centrifuge the collected tissue suspension at $150 \times g$ for $5 \mathrm{~min}$, and carefully aspirate the supernatant. Resuspend the tissue in sterile filtered HBSS containing $3 \mathrm{mg} / \mathrm{mL}$ Collagenase Type IV; $10-20 \mathrm{~mL}$ per tissue specimen is generally sufficient, depending on the amount of tissue obtained. Allow the enzymatic digestion to proceed for $30 \mathrm{~min}$ or longer with constant shaking at $37{ }^{\circ} \mathrm{C}$ until a suspension of isolated cells is obtained. Centrifuge digested tissue for $5 \mathrm{~min}$ at $150 \times g$ and remove the collagenase solution. Resuspend the cells in $10 \mathrm{~mL}$ of Growth Medium and plate in a $10 \mathrm{~cm}$ 
tissue culture dish. Incubate at $37{ }^{\circ} \mathrm{C}$ in a humidified $5 \% \mathrm{CO}_{2}$ incubator overnight. After 24 $\mathrm{h}$, remove the supernatant containing non-adherent cells and tissue remnants, and replace with fresh Growth Medium. At this time, visual examination will show thyrocytes aggregated into follicle-like structures. These follicle structures will disperse over a few days, and cells should form a confluent monolayer within 5-7 d after isolation (see Note 5).

Cells should be verified for thyroid-specific gene expression such as $T G, T P O, N I S, D I O 2$, and TSHR expression via quantitative RT-PCR. Cultures should be discarded if initial expression of these genes is not detected, or if values later deviate significantly from their baseline expression level. In particular, any large change in TSHR mRNA level (i.e., tenfold reduction from the original level) indicates a loss of differentiated state. Additionally, any failure of cells to respond to stimulation with TSH, especially when measuring cAMP generation, indicates that the culture should be discarded.

\subsection{Cell Maintenance and Propagation (see Note 1)}

Propagate/maintain human thyrocytes in Growth Medium at $37{ }^{\circ} \mathrm{C}$ in a humidified $5 \% \mathrm{CO}_{2}$ incubator. In contrast to commonly used rodent thyrocyte models, no additional growth factors, hormones, or supplements are necessary. Typical doubling time following the first passage is approximately $72-96 \mathrm{~h}$. If at any time proliferation slows significantly (doubling time $>120 \mathrm{~h}$ ), the culture should be discarded. Moreover, as stated above, a steady decrease of expression levels of thyroid-specific genes $T G, T P O, N I S, D I O 2$, and TSHR compared to early passages is an indicator for discontinuation of the primary cells. Cultures are generally viable and responsive for 9-12 passages (approximately 6-8 weeks following tissue isolation); however, as with all primary cells, experiments are best performed with early passage cells when possible.

Human thyrocytes respond best when at or near confluency. They will continue to proliferate somewhat after appearing $100 \%$ confluent, but under normal circumstances will not overgrow the culture vessel or start growing on top of each other as they are contact inhibited. Despite this, cells should (under most circumstances) be harvested at least once per week to avoid the deposition of excessive extracellular matrix and related proteins, which will make the cells clump and impede their removal from tissue culture vessels (see Note 6). If cells are not passaged, media should be changed twice per week.

Generally, a confluent dish of thyrocytes should be passaged 1:2-3 to maintain sufficient density but allow for propagation. Aspirate Growth Medium and wash dish with a sufficient volume of PBS (no calcium/magnesium). Remove (see Note 2) the PBS and add a small volume (i.e., $2 \mathrm{~mL}$ for a $10 \mathrm{~cm}$ dish) of $0.25 \%$ Trypsin/EDTA to the cells. Incubate at $37{ }^{\circ} \mathrm{C}$ for $2 \mathrm{~min}$. Cells will be rounded and mostly detached. If cells are not detached, gentle tapping of the dish will generally resolve this. Quench the trypsin with an equal or greater volume of Growth Medium and pipette up and down several times to disperse any clumps. Minimize time that cells are out of the incubator and/or unattached. Replate cells for propagation or experiments as needed. 


\subsection{Plating and Experimental Considerations}

Thyrocytes can be plated at moderate density ( $250 \%$ ) and allowed to grow to confluency before experiments are performed, as long as excessive matrix is not deposited during the proliferation period. Alternatively, more reproducible results can be obtained by plating cells at or near confluency for immediate use. Plating densities for this approach using common well sizes are listed below. Cells should be plated using Growth Medium and allowed to attach for at least $6 \mathrm{~h}$ but preferably overnight ( see Notes 3 and 4). Twenty-four hours prior to the experiment, cells should be arrested by replacing the Growth Medium with Arrest Medium (containing $0.1 \%$ BSA rather than $10 \%$ FBS). Thyrocytes can be maintained in $0.1 \%$ BSA Medium for at least 7 days with no significant cell death.

\begin{tabular}{llll}
\hline $\begin{array}{l}\text { Plate } \\
\text { size }\end{array}$ & $\begin{array}{l}\text { Experiment } \\
\text { plating }\end{array}$ & $\begin{array}{l}\text { Culture } \\
\text { plating }\end{array}$ & $\begin{array}{l}\text { Media } \\
\text { vol. }\end{array}$ \\
\hline $24 \mathrm{w}$ & $0.8 \times 10^{5}$ & & $500 \mu \mathrm{L}$ \\
$12 \mathrm{w}$ & $1.0-1.5 \times 10^{5}$ & & $1 \mathrm{~mL}$ \\
$10 \mathrm{~cm}$ & $1.5 \times 10^{6}$ & $1.0 \times 10^{6}$ & $10 \mathrm{~mL}$ \\
$15 \mathrm{~cm}$ & & $2.5-3.0 \times 10^{6}$ & $30 \mathrm{~mL}$ \\
$\mathrm{~T}-175$ & & $3.0-4.0 \times 10^{6}$ & $40 \mathrm{~mL}$ \\
\hline
\end{tabular}

\subsection{Freezing/Thawing}

Thyrocyte cultures can be frozen at $-80{ }^{\circ} \mathrm{C}$ for storage. Freezing is most successful at lower passages, and recovery is less successful with each subsequent freeze/thaw cycle. Harvest cells as usual with Trypsin/EDTA and quench with Growth Medium. Centrifuge the cell suspension at $150 \times g$ for 5 min and remove the media. Resuspend cells in Freezing Medium at a concentration of $2.0-3.0 \times 10^{6}$ cells $/ \mathrm{mL}$ and prepare $1 \mathrm{~mL}$ aliquots in cryogenic vials. Transfer vials immediately to a cryofreeze container with isopropanol and place the sealed container in a $-80{ }^{\circ} \mathrm{C}$ freezer overnight. Vials should be transferred to a liquid nitrogen tank for long-term storage.

To thaw, suspend vial in a $37{ }^{\circ} \mathrm{C}$ water bath with gentle shaking for $1-2 \mathrm{~min}$, until ice just disappears. Ensure that vial is not submerged and that water does not get into the cap. Thoroughly wipe down the vial with ethanol and dry, then replate frozen cells into a $10 \mathrm{~cm}$ dish containing $10 \mathrm{~mL}$ of warm Growth Medium. Immediately place the dish in a $37^{\circ} \mathrm{C}$ incubator. Media should be changed the following day to remove DMSO. Properly frozen and thawed cells should look healthy after $48 \mathrm{~h}$, and will be ready for passage from the 10 $\mathrm{cm}$ dish within 2-4 days after thawing.

\section{Notes}

1. Take special care to not work with multiple cell types at the same time. Primary cells such as thyrocytes are particularly vulnerable to contamination by other cell types, especially those that proliferate quickly (such as immortalized cell lines). Care also should be taken to not work with multiple donor cultures or normal and non-normal (Graves' disease, cancer) cell types simultaneously. 
2. $0.25 \%$ Trypsin/EDTA is recommended for harvesting cells; a $0.05 \%$ Trypsin solution may work but is not reliable for thyrocytes.

3. Thyrocytes need some time to recover between plating and experiments because trypsin cleaves the ectodomain of the TSHR. TSHR cleavage also occurs with most preparations of collagenase, likely due to trypsin contamination of the unpurified enzyme. Forty-eight hours after plating is generally sufficient to allow for TSHR recovery from de novo synthesis.

4. Under circumstances where TSHR cleavage will interfere with the experiment, such as labeling of the TSHR for flow cytometry or immunohistochemistry, an enzyme-free dissociation buffer can be utilized in place oftrypsin to harvest cells. Enzyme-free dissociation buffer should also be used when cells will be passaged multiple times during an experiment when sufficient recovery time is not possible.

5. Thyrocyte morphology varies widely with donor and disease state. The most typical morphology of thyrocytes derived from normal tissue is "fibroblast-like" (being somewhere between epithelial and fibroblast in appearance) when cells are maintained under proliferating conditions (Growth Medium). However, some cultures will maintain a more traditional epithelial or "cobblestone" appearance even in the presence of high serum concentrations. Cells with a fibroblast-like appearance revert to a more typical epithelial morphology following the addition of TSH (see Fig. 1).

6. When not passaged frequently, thyrocytes will deposit significant extracellular matrix. This matrix accumulation makes cells more difficult to harvest and can lead to loss of responsiveness during experiments. Thus cells should be harvested at least every 7-10 days. Additionally, excessive matrix can make the use of certain reagents (particularly peptides and some transfection methods) less effective. Care should be taken to optimize such experiments (i.e., by using freshly passaged cells or finding alternative methods).

\section{Acknowledgment}

This work was supported by the Intramural Research Program of the National Institute of Diabetes and Digestive and Kidney Diseases, National Institutes of Health (Z01 DK011006).

\section{References}

1. Kimura T, Keymeulen AV, Golstein J, Fusco A, Dumont JE, Roger PP (2001) Regulation of thyroid cell proliferation by TSH and other factors: a critical evaluation of in vitro models. Endocr Rev 22:631-656 [PubMed: 11588145]

2. Westermark B, Karlsson FA, Wålinder O (1979) Thyrotropin is not a growth factor for human thyroid cells in culture. Proc Natl Acad Sci U S A 76:2022-2026 [PubMed: 221911]

3. Williams DW, Wynford-Thomas D, Williams ED (1987) Control of human thyroid follicular cell proliferation in suspension and monolayer culture. Mol Cell Endocrinol 51:33-40 [PubMed: 3297847] 
4. Van Keymeulen A, Dumont JE, Roger PP (2000) TSH induces insulin receptors that mediate insulin costimulation of growth in normal human thyroid cells. Biochem Biophys Res Commun 279:202207 [PubMed: 11112439]

5. Morgan SJ, Neumann S, Marcus-Samuels B, Gershengorn MC (2016) Thyrotropin stimulates differentiation not proliferation of normal human thyrocytes in culture. Front Endocrinol (Lausanne) 7:168 [PubMed: 28082948]

6. Morgan SJ, Neumann S, Marcus-Samuels B, Gershengorn MC (2016) Thyrotropin and insulin-like growth factor 1 receptor crosstalk upregulates sodium-iodide symporter expression in primary cultures of human Thyrocytes. Thyroid 26:1794-1803 [PubMed: 27638195]

7. Neumann S, Huang W, Titus S, Krause G, Kleinau G, Alberobello AT, Zheng W, Southall NT, Inglese J, Austin CP, Celi FS, Gavrilova O, Thomas CJ, Raaka BM, Gershengorn MC (2009) Smallmolecule agonists for the thyrotropin receptor stimulate thyroid function in human thyrocytes and mice. Proc Natl Acad Sci U S A 106:12471-12476 [PubMed: 19592511] 

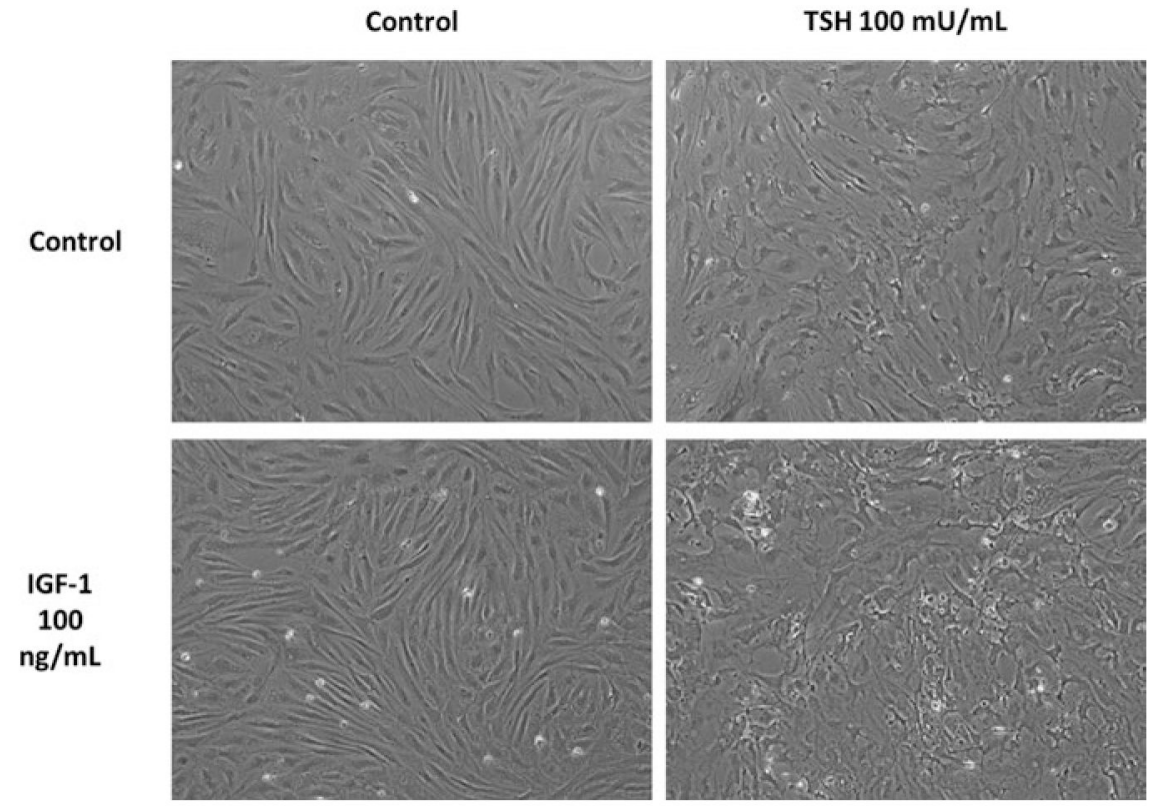

Fig. 1.

TSH alone or in combination with IGF-1 induces robust morphological changes. Images were taken at $10 \times$ magnification of control cells and those stimulated with $100 \mathrm{mU} / \mathrm{mL}$ TSH, $100 \mathrm{ng} / \mathrm{mL}$ IGF-1, or the combination for 7 days 